\title{
A multi-centric retrospective study of poisoning in children in 3 Medical College Hospitals across 3 different states in India
}

\author{
*Arijit Das ${ }^{1}$, Yashwant Kumar Rao ${ }^{2}$, Madhulata Pandey ${ }^{3}$, Ritesh Singh $^{4}, \operatorname{Radhabinod~Pal}^{5}$
}

Sri Lanka Journal of Child Health, 2015; 44(4): 209-212

\begin{abstract}
:
Introduction: The prevalence and types of poisoning vary in different geographical locations.

Objectives: To study poisoning among children in 3 medical college centres across 3 different states in India.
\end{abstract}

Method: A multi-centric retrospective study was conducted from March 2013 to February 2014. The collected data was tabulated and analysed and results were evaluated.

Results: A total of 290 cases of poisoning in the 3 Medical Colleges was included in the study. Poisoning cases constituted about $1 \%$ of hospital admissions. The commonest age group was 1-5 years. Kerosene oil constituted $30.3 \%$ of poisoning cases. Snake bite envenomation constituted $10 \%$ of poisoning. Corrosive poisons constituted $7.5 \%$ and drugs $6.0 \%$ of poisoning. There were 12 deaths.

Conclusions: Kerosene oil was the commonest cause of poisoning in children in all 3 centres. Envenomation due to snake bites was the next common cause. Overall mortality rate was $4.1 \%$.

(Key Words: Poisoning, children, India)

$\overline{{ }^{1} \text { Assistant Professor, Dept. of Paediatrics, College }}$ of Medicine and JNM Hospital, Kalyani, Nadia, West Bengal, ${ }^{2}$ Assistant Professor, Dept. of Paediatrics, GSVM Medical College, Kanpur, Uttar Pradesh, ${ }^{3}$ Assistant Professor, Dept. of Paediatrics, Manipal Institute of Medical Sciences, Sikkim, ${ }^{4}$ Assistant Professor, Dept. of Community Medicine, College of Medicine \& JNM Hospital, Kalyani, West Bengal, ${ }^{5}$ RMO cum Clinical Tutor, Dept. of Paediatrics, Bankura Sammilani Medical College, West Bengal, India

*Correspondence: drarijitdas@gmail.com

Received on 28 October 2014: Accepted after revision on 19 December 2014

The authors declare that there are no conflicts of interest

Open Access Article published under the Creative

Commons CC-BY-NC-ND Licence.

\section{Introduction}

Although, most cases of poisoning occur below the age of 5 years, worldwide ${ }^{1}$, the magnitude of the problem and fatality varies according to the socioeconomic status, level of industrialization, agricultural activities, cultural practices related to supervision of children and local beliefs and customs ${ }^{1}$. These factors vary greatly according to regions in a vast and diverse country like India.

\section{Objective}

To study poisoning among children in 3 medical college centres across 3 different states in India.

\section{Method}

A one year retrospective study was designed to collect hospital admission data from 3 medical college hospitals in 3 different states across India, from March 2013 to February 2014. The hospitals were: College of Medicine \& JNM Hospital (COM \& JNMH), GSVM Medical College Kanpur and Manipal Institute of Medical Sciences, Sikkim. A proforma was developed to collect data such as age, sex, location (rural/ urban), specific type and mode of poisoning. Data was collected from the Paediatrics Admission Registers of the 3 medical college hospitals. All suspected 'poisoning' cases were included in the study.

\section{Results}

A total of 296 cases of poisoning were enlisted in the 3 Medical Colleges but 6 Bed Head Tickets could not be retrieved at COM \& JNMH. Thus, 290 cases of poisoning were included in study. Distribution of poisoning cases in the 3 Medical Colleges during study period is shown in Table 1.

Table 1: Distribution of poisoning cases in the 3 Medical Colleges during study period

\begin{tabular}{|l|c|c|}
\hline Medical College & $\begin{array}{c}\text { Total } \\
\text { admissions }\end{array}$ & $\begin{array}{c}\text { Poisoning } \\
\text { No. (\%) }\end{array}$ \\
\hline COM \& JNMH & 5432 & $191(1.5)$ \\
\hline Kanpur & 8053 & $83(1.0)$ \\
\hline Sikkim Manipal & 1673 & $16(1.0)$ \\
\hline
\end{tabular}


Sex distribution of the poisoning cases in the 3 centres is shown in Table 2. The location (rural/ urban) of the poisoning is shown in Table 3 . The age distribution of cases of poisoning is shown in Table 4. The mode of poisoning is shown in Table 5 . The causes of poisoning in the 3 medical college hospitals are shown in Table 6.
Table 3: Location (ruraLurban) of poisoning

\begin{tabular}{|l|c|c|}
\hline Medical College & $\begin{array}{c}\text { Rural } \\
\text { No. (\%) }\end{array}$ & $\begin{array}{c}\text { Urban } \\
\text { No. (\%) }\end{array}$ \\
\hline COM \& JNMH & $143(74.9)$ & $48(25.1)$ \\
\hline Kanpur & $33(39.8)$ & $50(60.2)$ \\
\hline Sikkim Manipal & $04(25.0)$ & $12(75.0)$ \\
\hline
\end{tabular}

Table 2: Sex distribution of poisoning cases

\begin{tabular}{|l|c|c|}
\hline Medical College & $\begin{array}{c}\text { Male } \\
\text { No. (\%) }\end{array}$ & $\begin{array}{c}\text { Female } \\
\text { No. (\%) }\end{array}$ \\
\hline COM \& JNMH & $106(55.5)$ & $85(44.5)$ \\
\hline Kanpur & $58(69.9)$ & $25(30.1)$ \\
\hline Sikkim Manipal & $12(75.0)$ & $04(25.0)$ \\
\hline
\end{tabular}

Table 4: Age distribution of cases of poisoning in the 3 Medical Colleges

\begin{tabular}{|l|c|c|c|c|c|}
\hline $\begin{array}{c}\text { Medical } \\
\text { College }\end{array}$ & $\begin{array}{c}<1 \text { year } \\
\text { Number }(\%)\end{array}$ & $\begin{array}{c}\mathbf{1 - 5} \text { years } \\
\text { Number }(\%)\end{array}$ & $\begin{array}{c}\text { 6-10 years } \\
\text { Number (\%) }\end{array}$ & $\begin{array}{c}>10 \text { years } \\
\text { Number (\%) }\end{array}$ & $\begin{array}{c}\text { Total } \\
\text { Number (\%) }\end{array}$ \\
\hline COM \& JNMH & $06(03.1)$ & $131(68.6)$ & $29(15.2)$ & $25(13.0)$ & $191(100)$ \\
\hline Kanpur & $00(0)$ & $52(62.7)$ & $24(28.9)$ & $07(08.4)$ & $83(100)$ \\
\hline Sikkim Manipal & $01(06.3)$ & $15(93.8)$ & $00(0)$ & $00(0)$ & $16(100)$ \\
\hline
\end{tabular}

Table 5: Mode of poisoning in the 3 Medical Colleges

\begin{tabular}{|l|c|c|c|}
\hline \multicolumn{1}{|c|}{ Medical College } & Accidental & Suicidal & Homicidal \\
\hline COM \& JNMH & 188 & 03 & 00 \\
\hline Kanpur & 71 & 12 & 00 \\
\hline Sikkim Manipal & 16 & 00 & 00 \\
\hline
\end{tabular}

Table 6: Causes of poisoning in the 3 medical colleges

\begin{tabular}{|l|c|c|c|c|}
\hline Cause of poisoning & $\begin{array}{c}\text { COM \& JNMH } n=191 \\
\text { No. (\%) }\end{array}$ & $\begin{array}{c}\text { Kanpur } n=83 \\
\text { No. (\%) }\end{array}$ & $\begin{array}{c}\text { Sikkim Manipal } n=16 \\
\text { No. (\%) }\end{array}$ & $\begin{array}{c}\text { Total } n=290 \\
\text { No. (\%) }\end{array}$ \\
\hline Kerosene oil & $61(31.9)$ & $22(26.5)$ & $05(31.3)$ & $88(30.3)$ \\
\hline Turpin Oil & $16(08.4)$ & $00(0.0)$ & $01(06.3)$ & $17(05.9)$ \\
\hline Snake bite & $21(11.0)$ & $08(09.6)$ & $00(0.0)$ & $29(10.0)$ \\
\hline Scorpion sting & $00(0.0)$ & $10(12.0)$ & $00(0.0)$ & $10(03.4)$ \\
\hline Organophosphates & $12(06.3)$ & $08(09.6)$ & $02(12.5)$ & $22(07.6)$ \\
\hline Carbamates & $05(02.6)$ & $01(01.2)$ & $00(0.0)$ & $06(02.1)$ \\
\hline Acid & $16(08.4)$ & $05(06.0)$ & $00(0.0)$ & $21(07.2)$ \\
\hline Alkali & $01(00.5)$ & $00(0.0)$ & $00(0.0)$ & $01(00.3)$ \\
\hline Drugs & $05(02.6)$ & $09(10.8)$ & $04(25.0)$ & $18(06.2)$ \\
\hline Rat Killer & $05(02.6)$ & $00(0.0)$ & $00(0.0)$ & $05(01.5)$ \\
\hline Naphthalene & $01(00.5)$ & $00(0.0)$ & $01(06.3)$ & $02(00.6)$ \\
\hline Dettol & $01(00.5)$ & $00(0.0)$ & $00(0.0)$ & $01(00.3)$ \\
\hline Gutkha & $02(01.0)$ & $00(0.0)$ & $00(0.0)$ & $02(00.6)$ \\
\hline Mosquito repellent & $00(0.0)$ & $00(0.0)$ & $01(06.3)$ & $01(00.3)$ \\
\hline Hair dye & $00(0.0)$ & $01(01.2)$ & $00(0.0)$ & $01(00.3)$ \\
\hline Datura & $00(0.0)$ & $08(09.6)$ & $00(0.0)$ & $08(02.8)$ \\
\hline Plant seed & $00(0.0)$ & $03(03.6)$ & $00(0.0)$ & $03(00.9)$ \\
\hline$*$ Unknown bites & $21(11.0)$ & $02(02.4)$ & $00(0.0)$ & $23(07.9)$ \\
\hline$* *$ Unknown & $24(12.6)$ & $06(07.2)$ & $02(12.5)$ & $32(11.0)$ \\
\hline Total & $191(100)$ & $83(100)$ & $16(100)$ & $290(100)$ \\
\hline
\end{tabular}

*Cases where despite definite history of sting / bite, offender could not be identified. **Unknown poisoning cases occurred through ingestion but the material could not be identified. 
Kerosene oil was the major cause of childhood poisoning in all three Medical Colleges constituting $30.3 \%$ of the total number of cases. Turpin oil, which is also a hydrocarbon, constituted $5-9 \%$ of the poisoning cases. Envenomation due to snake bite constituted $10 \%$ of poisoning whilst that due to scorpion sting constituted $3.4 \%$ of the poisoning cases. Drug poisoning constituted $6.2 \%$ of total poisoning. Of the corrosive poisons acid and alkali constituted $7.5 \%$ of the total.

There were 12 deaths giving an overall mortality rate of $4.1 \%$. This comprised $5(2.6 \%)$ cases from College of Medicine \& JNMH Hospital, 6 (7.2\%) cases from GSVM Medical College Hospital, Kanpur and $1(6.3 \%)$ case from Manipal Institute of Medical Sciences, Sikkim. Among the 275 accidental poisoning cases there were 8 deaths giving a mortality rate of $2.9 \%$. Among the 15 suicidal poisoning cases there were 4 deaths giving a mortality rate of $26.7 \%$.

\section{Discussion}

Poisoning in children is particularly common below 5 years of age ${ }^{1}$. In this multi-centric, retrospective study, we found out that the hospital admission rates $(1.5 \%, 1 \% \& 0.95 \%$ in $\mathrm{COM} \& \mathrm{JNMH}$, Kanpur \& Sikkim Manipal, respectively) due to poisoning and the predominant age groups were similar in all 3 centres conforming to previous studies $^{1-3}$. Males were predominantly involved in all 3 centres. The difference in number of cases from rural and urban population varied in the 3 centres, probably due to different area of catchment.

Kerosene oil was the most common cause of poisoning in all three centres and this was in accordance with previous studies ${ }^{4-11}$. Turpin oil, a hydrocarbon like kerosene oil, accounted for 5.9\% of total poisoning. Whilst envenomation due to snake bite was a feature in both COM \& JNMH and GSVM Medical College Hospital, Kanpur, envenomation due to hornet stings was seen only in GSVM Medical College Hospital, Kanpur. In the 16 cases of poisoning seen in Sikkim Manipal there were no cases of envenomation. Drugs were a commoner cause of poisoning in Kanpur and Sikkim Manipal compared to COM \& JNMH. This is probably due to a large percentage of children in those two centres coming from urban areas. This variation is however, not a feature of earlier studies $^{12}$. Acid poisoning was the most common cause of corrosive poisoning among children accounting for $7.2 \%$ of total poisoning. The mortality rate varied from $2.6 \%$ to $7.2 \%$ in the 3 medical college hospitals.

\section{Conclusions}

- Kerosene oil was the commonest cause of poisoning in children in all 3 centres.

- Envenomation due to snake bites was the second common cause of poisoning in this study.

- The overall mortality rate was $4.1 \%$ in the 3 medical college hospitals.

\section{References}

1. World Health organization. World report on child injury prevention, 2008. Geneva (Switzerland): WHO; 2008.

2. Fernando R, Fernando DN. Childhood poisoning in Sri Lanka. Indian Journal of Pediatrics 1997; 64:457-560. http://dx.doi.org/10.1007/BF02737748 PMid: 10771874

3. Ballesteros MF et al. Differential ranking of causes of fatal versus non-fatal injuries among US children. Injury Prevention, 2003, 9:173-6.

http://dx.doi.org/10.1136/ip.9.2.173

PMid: 12810747 PMCid: PMC1730956

4. Dutta AK et al. Poisoning in children: Indian scenario. Indian Journal of Pediatrics, 1998; 65:365-70. http://dx.doi.org/10.1007/BF02761129 PMid: 10771987

5. Abu-Ekteish F. Kerosene poisoning in children: a report from Northern Jordan. Tropical Doctor 2002; 32:27-9.

PMid: 11991021

6. Chibwana C, Mhango $\mathrm{T}$, Molyneux E. Childhood poisoning at the Queen Elizabeth Central Hospital, Blantyre, Malawi. East African Medical Journal 2001; 78:292-5.

http://dx.doi.org/10.4314/eamj.v78i6.9021 PMid: 12002105

7. Barss $\mathrm{P}$ et al. Injury prevention: an international perspective New York, NY, Oxford University Press, 1998.

8. Singh $\mathrm{H}$ et al. Management of accidental kerosene ingestion. Annals of Tropical Paediatrics 1992; 12:105-9. PMid: 1376577 
9. Chitsike I. Acute poisoning in a paediatric intensive care unit in Harare. Central African Journal of Medicine 1994; 40:315-9.

PMid: 7859273

10. Gupta $\mathrm{S}$ et al. Trends in poisoning in children: experience at a large referral teaching hospital. National Medical Journal of India 1998; 11:166-8.

PMid: 9808971

11. Akhtar S, Gulali RR, Al-Anezi F. Risk factors in acute poisoning in children: a retrospective study. Kuwait Medical Journal 2006; 38:33-6.
12. O'Connor PJ. Differentials in poisoning rates of young Australian children according to residential location and geographical remoteness. Injury Prevention 2005; 11:204-6.

http://dx.doi.org/10.1136/ip.2004.005926

PMid: 16081746 PMCid: PMC1730237 